\title{
Large genomic rearrangements in BRCA1 and BRCA2 genes in breast and ovarian cancer families in Poland
}

Helena Bielecka*, Bohdan Górski

From Annual Conference on Hereditary Cancers 2010 Szczecin, Poland. 10-11 December 2010

Mutations in the BRCA1 and BRCA2 genes predispose women to breast and ovarian cancer. The large majority of the alterations identified in these genes are point mutations and small insertion/deletion. However, an increasing number of large genomic rearrangements are being identified, especially in BRCA1. To date 161 and 39 gene alterations have been described in the literature, approximately for BRCA1 and BRCA2. Just few large genomic rearrangements of BRCA1 gene have been reported in Poland.

Technical limitations of conventional PCR-based methods are cause that gross rearrangements can be overlooked. It has been suggest that about $30 \%$ of mutations in the BRCA1 gene are missed by standard mutation detection methods. We use Multiplex Ligationdependent Probe Amplification (MLPA) to analyze BRCA1/2 rearrangements in 300 unrelated patients with strong family history of breast and/or ovarian cancer negative for BRCA1 Polish founder mutation.

The purpose of this study is establish the prevalence of BRCA1 and BRCA2 large genomic rearrangements in patients with hereditary breast and/or ovarian cancer of Polish population.

Published: 12 January 2012

doi:10.1186/1897-4287-10-S1-A1

Cite this article as: Bielecka and Górski: Large genomic rearrangements in BRCA1 and BRCA2 genes in breast and ovarian cancer families in Poland. Hereditary Cancer in Clinical Practice 2012 10(Suppl 1):A1.

International Hereditary Cancer Center, Department of Genetics and

Pathology, Pomeranian Medical University, Szczecin, Poland
Submit your next manuscript to BioMed Central and take full advantage of:

- Convenient online submission

- Thorough peer review

- No space constraints or color figure charges

- Immediate publication on acceptance

- Inclusion in PubMed, CAS, Scopus and Google Scholar

- Research which is freely available for redistribution

Submit your manuscript at www.biomedcentral.com/submit
() Biomed Central
C Biomed Central

(c) 2012 Bielecka and Górski; licensee BioMed Central Ltd. This is an open access article distributed under the terms of the Creative Commons Attribution License (http://creativecommons.org/licenses/by/2.0), which permits unrestricted use, distribution, and reproduction in any medium, provided the original work is properly cited. 